Article

\title{
Structural Features and Rheological Properties of a Sulfated Xylogalactan-Rich Fraction Isolated from Tunisian Red Seaweed Jania adhaerens
}

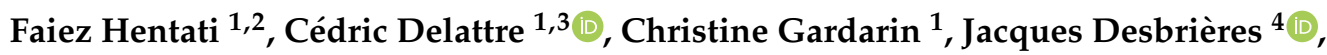

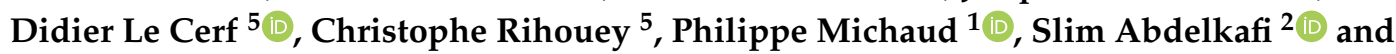 \\ Guillaume Pierre $1, * \mathbb{D}$
}

1 CNRS, SIGMA Clermont, Institut Pascal, Université Clermont Auvergne, F-63000 Clermont-Ferrand, France; faizhentati@gmail.com (F.H.); cedric.delattre@uca.fr (C.D.); christine.gardarin@uca.fr (C.G.); philippe.michaud@uca.fr (P.M.)

2 Unité de Biotechnologie des Algues, Biological Engineering Department, National Engineering School of Sfax, University of Sfax, 3038 Sfax, Tunisia; slim.abdelkafi@enis.tn

3 Institut Universitaire de France (IUF), 1 rue Descartes, 75005 Paris, France

4 Université de Pau et des Pays de l'Adour, IPREM, Helioparc Pau Pyrénées, 2 avenue P. Angot, 64053 Pau CEDEX 9, France; jacques.desbrieres@univ-pau.fr

5 UNIROUEN, INSA Rouen, CNRS, PBS, Normandie Univ, 76000 Rouen, France; didier.lecerf@univ-rouen.fr (D.L.C.); christophe.rihouey@univ-rouen.fr (C.R.)

* Correspondence: guillaume.pierre@uca.fr; Tel.: +33-(0)4-7340-7422; Fax: +33-(0)4-7340-7829

Received: 23 December 2019; Accepted: 20 February 2020; Published: 1 March 2020

\begin{abstract}
A novel sulfated xylogalactan-rich fraction (JSP for J. adhaerens Sulfated Polysaccharide) was extracted from the red Tunisian seaweed Jania adhaerens. JSP was purified using an alcoholic precipitation process and characterized by Attenuated Total Reflectance-Fourier-transform infrared spectroscopy (ATR-FTIR), high-pressure size exclusion chromatography (HPSEC) with a multi-angle laser light scattering (MALLS), gas chromatography coupled to mass spectrometry (GC-MS) and nuclear magnetic resonance spectroscopy (NMR, 1D and 2D). JSP was then evaluated regarding its physicochemical and rheological properties. Results showed that JSP was mainly composed of an agar-like xylogalactan sharing the general characteristics of corallinans. The structure of JSP was mainly composed of agaran disaccharidic repeating units $(\rightarrow 3)-\beta$-D-Gal $p-(1,4)-\alpha-\mathrm{L}-\mathrm{Gal} p-(1 \rightarrow)_{\mathrm{n}}$ and $(\rightarrow 3)-\beta-\mathrm{D}-\mathrm{Gal} p-(1,4)-3,6-\alpha$-L-AnGal $p-(1 \rightarrow)_{\mathrm{n}}$, mainly substituted on $O-6$ of $(1,3)-\beta$-D-Gal $p$ residues by $\beta$-xylosyl side chains, and less with sulfate or methoxy groups. $(1,4)-\alpha-\mathrm{L}-\mathrm{Gal} p$ residues were also substituted by methoxy and/or sulfate groups in the O-2 and O-3 positions. Mass-average and number-average molecular masses $\left(\mathrm{M}_{\mathrm{w}}\right)$ and $\left(\mathrm{M}_{\mathrm{n}}\right)$, intrinsic viscosity $([\eta])$ and hydrodynamic radius $\left(R_{h}\right)$ for JSP were, respectively, $8.0 \times 10^{5} \mathrm{~g} / \mathrm{mol}, 1.0 \times 10^{5} \mathrm{~g} / \mathrm{mol}, 76 \mathrm{~mL} / \mathrm{g}$ and $16.8 \mathrm{~nm}$, showing a flexible random coil conformation in solution. The critical overlap concentration $C^{*}$ of JSP was evaluated at $7.5 \mathrm{~g} / \mathrm{L}$ using the Williamson model. In the semi-diluted regime, JSP solutions displayed a shear-thinning behavior with a great viscoelasticity character influenced by temperature and monovalent salts. The flow characteristics of JSP were described by the Ostwald model.
\end{abstract}

Keywords: Corallinales; sulfated xylogalactan; Jania adhaerens; polysaccharide; rheology

\section{Introduction}

Water-soluble sulfated galactans are the main constituents of the non-fibrillar cell walls and intercellular matrix of most red algae (Rhodophyta) [1-3]. They show a linear backbone consisting of alternating (1,4)-linked $\alpha$-Gal (and/or 3,6- $\alpha$-AnGal) and (1,3)-linked $\beta$-Gal units. The latter residue 
always belongs to the D-series, while the former ( $\alpha$-Gal) can occur as D-(carrageenans) or L-(agarans) series [4-7]. The main backbone can be substituted by pyruvic acid ketals, sulfate, $O$-glycosyl and/or methyl groups and also by side chains, giving rise to great structural changes along the galactan chain. These structural changes affect the physicochemical and rheological behaviors of these polymers. So far, it has been reported that sulfated galactans exhibit numerous biological properties, including antioxidant, anticoagulant, antinociceptive, immunomodulatory, anticancer, gastroprotective, anti-inflammatory, antithrombotic and antiproliferative [1,6-14]. Marine seaweed (Phaeophyceae and Rhodophyceae) cell wall polysaccharides also hold great promise as a raw material for feed, food, and biofuel production. Through metabolic engineering, seaweeds (micro- and macroalgae) are attracting growing attention as an alternative source of biofuel by converting the seaweed biomass and, in particular, the cell wall, which is rich in carbohydrates, into liquid biofuels [15].

Galactans are currently used as thickening, gelling, and stabilizing agents in food, cosmetic, and pharmaceutical fields [1,10-16]. However, sulfated galactans produced by Corallinales are less studied, probably because of their strong calcareous cover, which decreases the production yield [17]. Up until now, only six species that produce sulfated galactan from the Corallinales order (Joculator maximus, Corallina pilulifera, Corallina officinalis, Bossiella cretacea, Bossiella orbigniana, Jania rubens and Lithothamnion heterocladum) have been reported [2-4,18-20]. Their common structural feature is an agaran main chain in which $(1,3)-\beta$-D-Galp residues are almost completely substituted in O-6 positions, mainly by $\beta$-D-Xylp side chains, but also by some sulfate groups. $\alpha$-L-Gal $p$ residues are also partially substituted by sulfate and methoxy groups in the $O-2$ position $[4,19,20]$. Some sulfate groups have also been reported on the O-3 position of the $\alpha$-L-Gal $p$ units. Note that 3,6-AnGal $p$ residues were previously reported in Jania rubens [3].

Jania adhaerens (J.V. Lamour) belongs to the Corallinales order and Corallinaceae algal family. This genus is widely present in the Mediterranean and Atlantic coasts and mostly found mixed with the brown alga Cystoseira crinita. To our knowledge, there is no data in the literature concerning some structural features and rheological properties of the polysaccharides extracted from J. adhaerens. Besides, this macroalgae is not used for ethnomedicine or as food by local populations. Today, Tunisia mainly imports phycocolloids and does not promote the macroalgae industry to produce agaroids at a large scale. Regarding these drawbacks and the strong ethnobotanic (endemic species) but also economic (climatic conditions, market potential in North Africa, etc.) potential of this algae, this work aimed to identify the value of Jania adhaerens as a new feedstock for producing agaroids. This paper deals with the extraction, purification and structural characterization of a sulfated xylogalactan-rich fraction (JSP) using Fourier-transform infrared spectroscopy (FTIR), high-pressure size exclusion chromatography (HPSEC) with a multi-angle laser light scattering (MALLS), gas chromatography coupled to mass spectrometry (GC-MS) and nuclear magnetic resonance spectroscopy (NMR). The physicochemical properties and rheological behavior of JSP were also evaluated to better comprehend its potential use as a hydrocolloid.

\section{Material and Methods}

\subsection{Marine Seaweed Collection and Processing}

The red seaweed Jania adhaerens J.V. Lamour (Rhodophyta, Corallinales) was collected at a $1 \mathrm{~m}$ depth from Tabarka in northern Tunisia ( $36^{\circ} 57^{\prime} 04.3^{\prime \prime} \mathrm{N}-8^{\circ} 44^{\prime} 30.4^{\prime \prime} \mathrm{E}$ ) in August 2018. Thalli of the seaweeds were cleaned with sea water then distilled water (avoiding contamination with epiphytes) and dried at $55^{\circ} \mathrm{C}$ for 11 days. The dried seaweeds were crushed by mechanical blender (Moulinex, France) into a fine powder and finally sieved with a $0.3 \mathrm{~mm}$ mesh size. Prior to polysaccharide extraction, a depigmentation of the powder was performed with acetone and $96 \%$ ethanol overnight under gentle stirring $(400 \mathrm{rpm})$ at room temperature. The depigmented powder was then dried at $50^{\circ} \mathrm{C}$ for $24 \mathrm{~h}$. All chemicals were purchased from Sigma-Aldrich and were of analytical grade. 


\subsection{Extraction and Purification of JSP}

Fifty grams of the depigmented powder were submitted to alkaline extraction with $0.3 \mathrm{M} \mathrm{NaOH}$ solution $(50 \mathrm{~g} / \mathrm{L})$ for $5 \mathrm{~h}$ at $90^{\circ} \mathrm{C}(\mathrm{pH} 9-9.5)$ under reflux and stirring (500 rpm) [16]. After filtrations through glass filters of porosity $2(40-100 \mu \mathrm{m})$ and then $3(16-40 \mu \mathrm{m})$ and centrifugation $(12,000 \mathrm{~g}$, $30 \mathrm{~min}, 20^{\circ} \mathrm{C}$ ), the supernatant was collected and then precipitated by three volumes of $-20^{\circ} \mathrm{C}$ cold ethanol $(96 \%, 12 \mathrm{~h})$ under gentle stirring $(250 \mathrm{rpm})$ at $4{ }^{\circ} \mathrm{C}$. The polysaccharide pellet was collected and solubilized in ultra-pure water $(300 \mathrm{~mL})$. The ethanolic precipitation and washing steps were repeated following the same procedure (five times) for removing salts (with control of conductimetry) and the polysaccharide was collected (pellet) after centrifugation $\left(8000 \mathrm{~g}, 4^{\circ} \mathrm{C}, 15 \mathrm{~min}\right)$. The final pellet was resolubilized in ultra-pure water and then freeze-dried at $-55^{\circ} \mathrm{C}$ for $48 \mathrm{~h}$ (Heto Power Dry PL600). The polysaccharide fraction was, finally, finely crushed and named JSP (Jania adhaerens sulfated xylogalactan-rich fraction).

\subsection{Colorimetric Assays}

Total carbohydrates were evaluated by the phenol-sulfuric acid method [21], using D-Gal as standard (Dubois method). Neutral and acid sugars were, respectively, quantified by the sulfuric resorcinol [22] and $m$-hydroxydiphenyl (MHDP) methods [23] using D-Gal and D-GlcA as standards and the correction method of Montreuil et al. [24]. The sulfation degree was evaluated by $\mathrm{BaCl}_{2} /$ gelatin turbidity as described by Dodgson and Price [25]. The content of 3,6-anhydrogalactose was quantified by the procedure of Yaphe and Arsenault [26] using D-Fru as standard. Pyruvic acetal content was estimated after sample hydrolysis by reaction with 2,4-dinitrophenylhydrazone [27]. Protein concentrations were determined by the Bradford [28] method using bovine serum albumin (BSA) as reference. Total phenolic compounds content was quantified according to the method of Folin-Ciocalteu [29] using gallic acid as reference. The conversion of conductivity into $\mathrm{NaCl}$ content was done assuming that $2 \mathrm{mS} / \mathrm{cm}$ were equivalent to $1 \mathrm{~g} / \mathrm{L}$ of $\mathrm{NaCl}$. All the measurements were repeated three times.

\subsection{Solvolytic Desulfation of Polysaccharide}

JSP aqueous solution $(20 \mathrm{~g} / \mathrm{L})$ was treated with Dowex cations exchange resin (Dowex Marathon C Sodium, $\mathrm{H}^{+}$form) during $3 \mathrm{~h}$, neutralized with pyridine $(99.8 \%$, $\mathrm{pH} 6.5-7)$ and concentrated by rotary evaporator (Rotavapor RII, BUCHI, Rungis Complexe, France). The solution (15-20 mL) was mixed three times with acetone $(99.8 \%, 50 \mathrm{~mL})$, concentrated again and then freeze-dried [30]. The resulting pyridinium salts were desulfated with $\mathrm{DMSO} / \mathrm{MeOH}$ anhydrous mixture $(30 \mathrm{~min}, 500 \mathrm{rpm}$ ) and then boiled at reflux for $3.5 \mathrm{~h}$ at $100{ }^{\circ} \mathrm{C}$. The solution was neutralized (1 M NaOH, $\mathrm{pH}$ 9-9.5), dialyzed (SnakeSkin Dialysis Tubing, $3.5 \mathrm{kDa}$ MWCO, $35 \mathrm{~mm}$ I.D, 35 feet) and freeze-dried. The obtained fraction was named JDP (desulfated fraction of JSP).

\subsection{ATR-FTIR Analysis}

FTIR spectra of JSP and JDP were obtained using a VERTEX 70 FTIR instrument with ATR A225 diamante (Bruker, Palaiseau, France). Fifty scans were measured at room temperature (referenced against air) ranging from 400 to $4000 \mathrm{~cm}^{-1}\left(4 \mathrm{~cm}^{-1}\right.$ resolution) and the infrared data were analyzed with OPUS 7.2 software.

\subsection{Structural Features}

\subsubsection{Determination of the Monosaccharides Composition}

Fifteen milligrams of JSP were hydrolyzed with TriFluoroacetic Acid (TFA) $(1.5 \mathrm{~mL}, 90 \mathrm{~min}$, $120{ }^{\circ} \mathrm{C}$ ) and the hydrolysate was evaporated at $60^{\circ} \mathrm{C}$ under nitrogen stream. The residual traces of acid were removed by adding $1 \mathrm{~mL}$ methanol (three times). Monosaccharides derivatization was carried out at room temperature for $2 \mathrm{~h}$ according to the protocols adapted from Pierre et al. 
(2012, 2014) using N,O-bis(trimethylsilyl)trifluoroacetamide (BSTFA)/chlorotrimethylsilane (TMCS) (99:1) [31,32]. After evaporation (nitrogen flow), the trimethylsilyl-O-glycosides residues were then solubilized in dichloromethane $(10 \mathrm{~g} / \mathrm{L})$. The standards (L-Rha, D-Rib, L-Fuc, L-Ara, D-Xyl, D-Man, D-Gal, D-Glc, D-GlcA, D-GalA, D-GalN, D-GalN) were subsequently prepared following the same method. The monosaccharides composition was determined by GC/MS coupled to electronic impact (EI) on an Agilent 6890 Series GC System coupled to a 5973 Network Mass Selective Detector (Agilent Technologies, Les Ulis, France). One microliter (sample/standard) was injected on an OPTIMA-1MS $(30 \mathrm{~m}, 0.32 \mathrm{~mm}, 0.25 \mu \mathrm{m})$ column with a helium total flow rate of $2.3 \mathrm{~mL} / \mathrm{min}$. The split ratio was set at 50:1 and the helium pressure at $8.8 \mathrm{psi}$. The temperature was made up at $100^{\circ} \mathrm{C}$ for $3 \mathrm{~min}$, then raised to $200^{\circ} \mathrm{C}\left(8^{\circ} \mathrm{C} / \mathrm{min}\right)$ maintaining for $1 \mathrm{~min}$ continuing, with a final increment to $215^{\circ} \mathrm{C}$ at $5^{\circ} \mathrm{C} / \mathrm{min}$ (runtime $19 \mathrm{~min} 50 \mathrm{~s}$ ). The ionization was performed by electronic impact (EI, $70 \mathrm{eV}$ ) with the trap temperature programmed at $150{ }^{\circ} \mathrm{C}$ and the target ion was programmed at $40-800 \mathrm{~m} / \mathrm{z}$. The injector temperature was fixed at $250{ }^{\circ} \mathrm{C}$.

\subsubsection{Molecular Weight Analysis by HPSEC-MALLS}

High-pressure size exclusion chromatography (HPSEC) equipped with three detectors on line: a multi-angle laser light scattering (MALLS) filled with a He-Ne laser at $690 \mathrm{~nm}$ and a K5 cell (50 $\mu \mathrm{L})$ (HELEOSII Wyatt Technology Corp., Goleta, CA, USA), a differential refractive index (DRI) (RID10 A Shimadzu, Kyoto, Japan) as well as a viscosimeter (Viscostar II, Wyatt Technology Corp., USA) were used to estimate macromolecular magnitudes $\left(M_{w}, M_{n}\right.$, PolyDispersity Index (PDI) $=M_{w} / M_{n}, R_{h}$ and $[\eta]$ ) of polysaccharides using a dn/dc of $0.15 \mathrm{~mL} / \mathrm{g}$. Columns (OHPAK SB-G guard column, OHPAK SB806 and $804 \mathrm{HQ}$ columns (Shodex)) were eluted with $0.1 \mathrm{M} \mathrm{LiNO}_{3}$ at $0.7 \mathrm{~mL} / \mathrm{min}$. The solvent was filtered through $0.1 \mu \mathrm{m}$ filter unit (Millipore), degassed and filtered using a $0.45 \mu \mathrm{m}$ filter upstream column. JSP $(2 \mathrm{~g} / \mathrm{L})$ was solubilized in $0.1 \mathrm{M} \mathrm{LiNO}_{3}$ solution for $24 \mathrm{~h}$ at room temperature under gentle stirring, filtered $(0.45 \mu \mathrm{m})$ and then injected through a $500 \mu \mathrm{L}$ full loop. All the data were analyzed using Astra 6.1 software package.

\subsubsection{NMR Spectroscopy}

JSP (sulfated) and JDP (desulfated) $(60 \mathrm{~g} / \mathrm{L})$, previously exchanged with deuterium (3 times) by repeated solubilization ( 3 times) in $\mathrm{D}_{2} \mathrm{O}(\mathrm{D}, 99.9 \%)$ and freeze-dried, were finally dissolved in $\mathrm{D}_{2} \mathrm{O}$ $(40 \mathrm{~g} / \mathrm{L})$ prior to NMR analysis. Spectra were performed at $60^{\circ} \mathrm{C}$ on a Bruker Avance 600 spectrometer (Bruker BioSpin MRI GmbH, Ettlingen, Germany) of $600 \mathrm{MHz}$ equipped with a Broad Band Fluorine Observation (BBFO) probe. NMR experiments were operated with a spectral width of $3000 \mathrm{~Hz}$ with the following acquisition parameters: (i) for ${ }^{1} \mathrm{H}$ experiments, recovery $=5 \mathrm{~s}$ (for a complete return after a $90^{\circ}$ pulse), acquisition mode $=2 \mathrm{~s}$, pulse $90^{\circ}=8 \mu \mathrm{sec}$; number of scans $=64$; and (ii) for ${ }^{13} \mathrm{C}$ experiments, number of scans $=16,384$, acquisition mode $=0.34 \mathrm{~s}$, recovery $=2 \mathrm{~s}$, pulse $=7 \mu \mathrm{sec}$, accumulation for $11 \mathrm{~h}$. 2D NMR spectra were applied using double-quantum filtered COrrelated SpectroscopY $\left({ }^{1} \mathrm{H}_{-}{ }^{1} \mathrm{H} \mathrm{COSY}\right)$ and nuclear Overhauser effect spectroscopy (NOESY).

\subsection{Rheological Investigations}

\subsubsection{Samples Preparation}

Solutions of JSP at different concentrations (from 0.25 to $2.0 \%, w / v$ ) were prepared by solubilizing the samples in ultra-pure water or in $0.5 \mathrm{M} \mathrm{NaCl}$ and $\mathrm{KCl}$ solutions after gentle stirring (400 rpm) until full dissolution for $4-5 \mathrm{~h}$ at room temperature. Later, the solutions were then stored at $4{ }^{\circ} \mathrm{C}$ for $48 \mathrm{~h}$ to obtain a full water-swelling polymer (biopolymer hydration) and for removal of bubbles.

\subsubsection{Rheological Measurements}

Rheological measurements were done using a rheometer AR-2000 (TA Instrument, Great Britain, Ltd., New Castle, DE, USA) fitted with a $40 \mathrm{~mm}$ cone-plate geometry (54 microns gap) and equipped 
with a Peltier heating system for accurate control. After loading, samples were held for $15 \mathrm{~min}$ before measurements to permit structure recovery and temperature equilibration. The solutions were then covered with a thin layer of hexadecane to prevent solvent evaporation during measurements $[29,33,34]$. The TA Instrument Rheology Advantage software (V5.7.0) was used to collect and analyze the rheological data. Rheological measurements were carried out in duplicate and the values of effectively overlapping traces were reported. Steady-shear flow properties for JSP solutions (from $0.25 \%$ to $2.0 \%$ ) $(w / v)$ were investigated at $25^{\circ} \mathrm{C}$ over the range of shear rate $(\dot{\gamma})$ from 0.001 to $1000 \mathrm{~s}^{-1}$. Solutions of $1.0 \%$ and $2.0 \%(w / v)$ were used to evaluate the effect of salts and temperature. Viscosity data were expressed using the Williamson model (Equation (1)) and the flow curves modeling were achieved using the Ostwald-de Waele (power-law) equation (Equation (2)):

$$
\begin{gathered}
\eta=\frac{\eta_{0}}{\left(1+(\lambda \cdot \dot{\gamma})^{(1-\mathrm{n})}\right)}, \\
\tau=\mathrm{k} \dot{\gamma}^{\mathrm{n}},
\end{gathered}
$$

where $\eta$ is the apparent viscosity (Pa.s), $\eta_{0}$ is the zero shear viscosity (Pa.s), $\tau(\eta \times \dot{\gamma})$ is the shear stress $(\mathrm{Pa}), \lambda$ is the transition time (s), $\dot{\gamma}$ is the shear rate $\left(\mathrm{s}^{-1}\right)$ and $\mathrm{n}$ is the flow index (dimensionless).

Oscillatory frequency sweep measurements of elastic modulus $G^{\prime}$ (storage modulus), viscous modulus $G^{\prime \prime}$ (loss modulus) and loss tangent $\left(\tan \delta=G^{\prime \prime} / G^{\prime}\right)$ (damping factor) were carried out at $25^{\circ} \mathrm{C}$ in a constant strain of $20 \%$ (or in linear viscoelastic range) over the set of angular frequency $(\omega)$ ranging from 0.01 to $10 \mathrm{~Hz}(0.063-62.83 \mathrm{rad} / \mathrm{s})$.

\section{Results and Discussion}

\subsection{Extraction Yield and Biochemical Composition}

The extraction yield and the overall biochemical composition of JSP are detailed in Table 1.

Table 1. Global composition of JSP.

\begin{tabular}{cccccccccc}
\hline $\begin{array}{c}\text { Extraction } \\
\text { Yield } \\
(\% w / w)\end{array}$ & $\begin{array}{c}\text { Total } \\
\text { Sugar } \\
(\% w / w)\end{array}$ & $\begin{array}{c}\text { Neutral } \\
\text { Sugar } \\
(\% w / w)\end{array}$ & $\begin{array}{c}\text { Uronic } \\
\text { Acid } \\
(\% w / w)\end{array}$ & $\begin{array}{c}\text { Sulfate } \\
(\% w / w)\end{array}$ & $\begin{array}{c}\text { Pyruvate } \\
(\% w / w)\end{array}$ & $\begin{array}{c}3,6-A n G a l \\
(\% w / w)\end{array}$ & $\begin{array}{c}\text { Proteins } \\
(\% w / w)\end{array}$ & $\begin{array}{c}{[N a C l]} \\
\text { eq. }(\%)\end{array}$ & $\begin{array}{c}\text { Conductimetry } \\
(\mu \mathrm{s} / \mathrm{cm})\end{array}$ \\
\hline & $70.34 \pm$ & $63.26 \pm$ & $5.63 \pm$ & $10.82 \pm$ & $0.44 \pm$ & $18.15 \pm$ & $0.81 \pm$ & 1.64 & 31.65 \\
\hline
\end{tabular}

The extraction yield of JSP was around 4.55\% (w/w) and close to those obtained by Zeid et al. [35], Navarro et al. [2], Maciel et al. [36] and Chiovitti et al. [37] for the extraction of galactans from the red seaweeds Pterocladia capillacea (6.46\%), L. heterocladum (6.20\%), Gracilaria birdiae (6.50\%) and Sarconema filiforme (6.0\%). This extraction yield was higher than those obtained from J. rubens ( $<1.4 \%), C$. officinalis $(0.3 \%)$ and B. orbigniana $(0.25 \%)$ [3,18], but remained much lower than those obtained by Lajili et al. [38], Fenoradosoa et al. [16] and Chattopadhyay et al. [39] for the red algae Laurencia obtusa $(12.80 \%)$, Halymenia durvillei ( 15-18\%) and Grateloupia indica (13.0\%). Overall, the extraction yield of sulfated galactans from Corallinales are probably lower due to their strong calcareous covers.

JSP was mainly composed of carbohydrates $(70.34 \%)$, principally neutral $(63.26 \%)$, with minor amounts of uronic acids $(5.63 \%)$, polyphenols $(0.74 \%)$, proteins $(0.81 \%)$ and pyruvates $(0.44 \%)$. These results were in accordance with the literature concerning sulfated galactans extracted from red seaweeds species, such as C. officinalis, J. rubens and H. durvillei $[16,18,40]$. The presence of sulfate groups $(10.82 \%)$ was in agreement with values reported for galactans isolated from J. rubens, C. officinalis and B. orbigniana $(7-15 \%)$ [18]. As seen in Table 1, the proportion of 3,6-anhydrogalactose (3,6-AnGal) was close to $18.15 \%$, confirming the great content of 3,6-AnGal residues obtained after an alkaline extraction [16]. Regarding the literature, this strong heterogeneity in extraction yields and global chemical compositions 
of sulfated galactans is largely dependent on the algal species, environmental factors and extraction procedures $[16,38]$.

\subsection{Structural Characterization of JSP}

\subsubsection{ATR-FTIR Spectroscopy}

The FTIR footprints of JSP and JDP fractions were performed and are shown in Figure 1. The absorption bands at 3331 and $2927 \mathrm{~cm}^{-1}$ were attributed, respectively, to $\mathrm{OH}$ - stretching and $\mathrm{CH}-$ asymmetric vibrations of polysaccharides [41,42]. The absorption signal around $1609 \mathrm{~cm}^{-1}$ was ascribed to (-COO-) carboxylate groups, whereas those at $1417 \mathrm{~cm}^{-1}$ suggested the presence of $(C=O)$ ester carbonyl groups of acid residues, confirming the weak electrolytic character of JSP (5.63\%) [41]. FTIR spectra showed characteristic bands $\left(1236,1073,1023,934\right.$ and $\left.875 \mathrm{~cm}^{-1}\right)$ of agar-like polysaccharide (agarans structure) $[1,37,38]$.

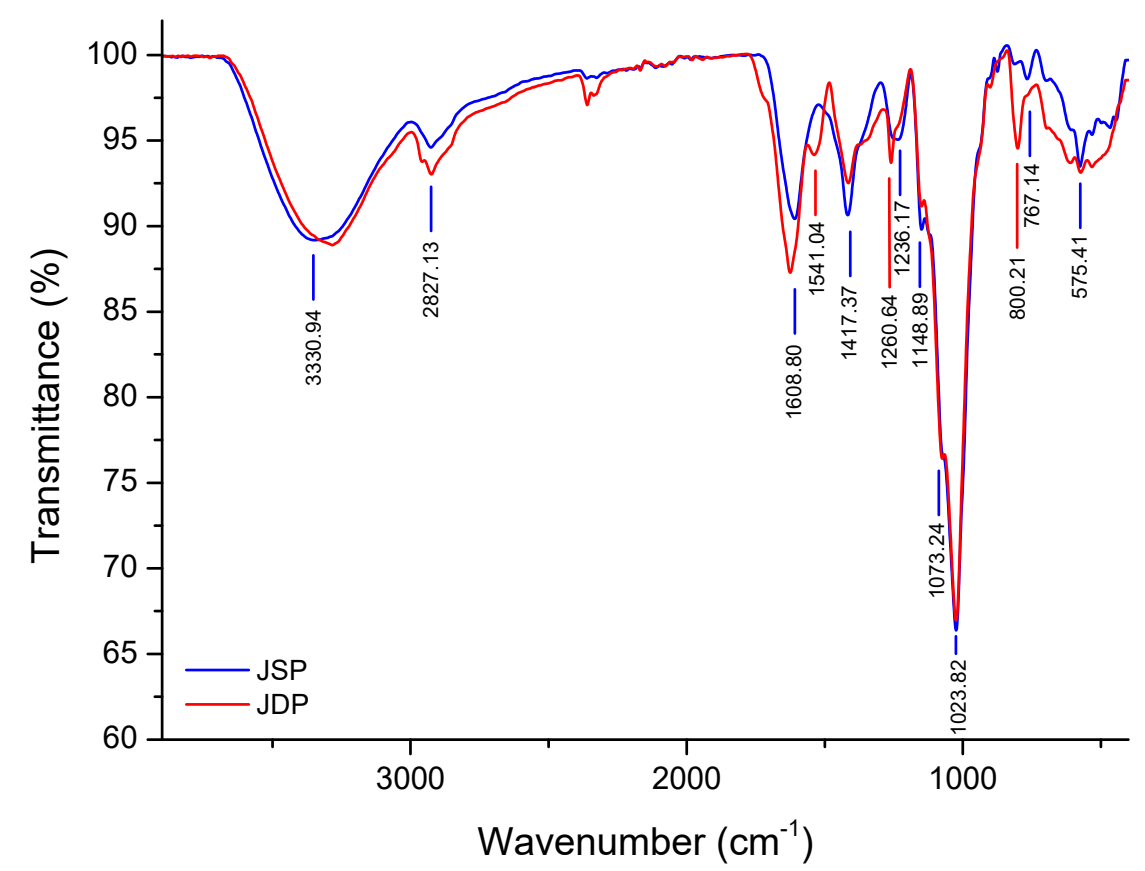

Figure 1. FTIR spectra of JSP (original sulfated fraction, in blue) and JDP (desulfated fraction, in red).

The absorption band observed at $1236 \mathrm{~cm}^{-1}$ could be attributed to asymmetric $\mathrm{O}=\mathrm{S}=\mathrm{O}$ stretching vibration of sulfate ester $[30,38,41]$. The peaks near to 1073 and $1148 \mathrm{~cm}^{-1}$ were assigned to C-O-C and $\mathrm{C}-\mathrm{O}$ glycosidic band vibrations, which suggested the presence of carbohydrates. The strong absorption peak near $1023 \mathrm{~cm}^{-1}$ corresponded to the stretching vibration of carbohydrates (pyranose ring of galactose units). The weak signal at around $935 \mathrm{~cm}^{-1}$ could be assigned to the vibration $\mathrm{C}-\mathrm{O}-\mathrm{C}$ bridge in 3,6- $\alpha$-L-AnGal $p$ residues [43-45].

The absorption region between 950 and $750 \mathrm{~cm}^{-1}$ was expanded to better determine the sulfate group position in agaran-type polysaccharides [11]. The characteristic region (agar-specific bands) between 855 and $830 \mathrm{~cm}^{-1}$ could be attributed, respectively, to 3-O-sulfate and/or 2-O-sulfate groups present in $\alpha$-L-Galp units [11], while the peaks at around 875 and $812 \mathrm{~cm}^{-1}$ were ascribed to $\left(6-\mathrm{O}-\mathrm{SO}_{3}{ }^{-}\right)$stretching of sulfate groups on $\beta$-D-Gal $p$ units and to the 3,6-AnGalp $\left(2-\mathrm{O}-\mathrm{SO}_{3}{ }^{-}\right)$residues, respectively $[1,46]$. Regarding the literature, alkaline treatment increased the intensity of the signal at $935 \mathrm{~cm}^{-1}\left(950-930 \mathrm{~cm}^{-1}\right)$ by conversion of $(1,4)$-linked $\alpha$-L-Gal $p\left(6-\mathrm{O}-\mathrm{SO}_{3}{ }^{-}\right)$to 3,6-AnGal $p[11,16]$.

JDP, which was obtained from JSP after desulfation (see Section 2.4.), showed a drop in intensities for the characteristic signals (region $800-1240 \mathrm{~cm}^{-1}$ ) corresponding to sulfate groups. This desulfation step, with a yield of $46.35 \%(w / w)$, was also confirmed by colorimetric assays $(2.08 \%)$. 


\subsubsection{Monosaccharide Composition}

Monosaccharide composition of JSP was determined by GC/MS analysis after acidic hydrolysis. As shown in Table 2, JSP was mainly composed of galactose $(62.35 \%)$, glucose $(20.0 \%)$ and xylose (15.41\%), but also small amounts of glucuronic acid $(2.24 \%)$.

Table 2. Monosaccharides composition of JSP.

\begin{tabular}{|c|c|c|c|}
\hline \multicolumn{4}{|c|}{ Monosaccharides Composition (Molar \%) } \\
\hline Gal & Xyl & Glc & GlcA \\
\hline 62.35 & 15.41 & 20.00 & 2.24 \\
\hline
\end{tabular}

Regarding the literature, galactose and xylose were the principal constitutive residues of polysaccharides extracted from red algae of the Corallinales order. Consequently, JSP could be a xylogalactan-rich fraction as already reported by Navarro and Stortz $[3,18]$ for sulfated polysaccharides extracted from other corallinans, such as J. rubens and C. officinalis. JSP presented a ratio of Galp/Xylp equal to 4.05 (Table 2). These results were in agreement with previous studies done on xylogalactans isolated from C. officinalis (2.9-4.4), J. rubens (2.6-3.5) and B. orbigniana (2.9-4.4) [3]. The Galp/Xylp ratio found in this paper was considerably higher than those described for xylogalactans derived from L. heterocladum (1.5-3) [2] but lower than those recorded for sulfated galactans isolated from Spyridia hypnoides and H. durvillei, which contained high Galp/Xylp ratios $(>10)[16,43]$.

Finally, the presence of polluting floridean starch (as indicated by Glc residues) is common, considering the used extraction and purification procedures, and was largely described for other corallinans in the literature $[3,18]$.

\subsubsection{NMR Investigations}

Several assignments were deduced by comparing the NMR results of JSP and JDP with the ${ }^{1} \mathrm{H} /{ }^{13} \mathrm{C}$ NMR spectra of (i) a sulfated xylogalactan from $C$. officinalis showing an alternating $\rightarrow 4)$ - $\alpha$-L-Gal $p$-(1,3)- $\beta$-D-Gal $p$-( $1 \rightarrow$ backbone devoid of 3,6-AnGal $p$, in which the C-6 of the $\beta$-D-Gal $p$ units is substituted almost completely, mainly by $\beta$-D-Xyl $p$ and also by sulfate groups, while the C-2 of $\alpha$-L-Gal $p$ moieties was partially substituted by sulfate and methoxy groups and the C-3 of the same unit also carries some sulfate groups [20]; (ii) a sulfated galactan extracted from J. maximus having a repeating backbone of $\rightarrow 3)-\beta-\mathrm{D}-\mathrm{Gal} p-(1,4)-\alpha-\mathrm{L}-\mathrm{Gal} p-(1 \rightarrow$, highly branched on the $O-2$ and $O-3$ of $\alpha-(1,4)-\mathrm{L}-\mathrm{Gal} p$ by short side chains and on the $O-6$ of $\beta-(1,3)-\mathrm{D}-\mathrm{Gal} p$ by terminal residues of $\beta$-D-Xyl $p$ [4]; (iii) a sulfated xylogalactan produced from J. rubens with a main backbone consisting of an agaran disaccharidic repeating unit $[\rightarrow 4)-\alpha$-L-Gal $p-(1,3)-\beta$-D-Gal $p-(1 \rightarrow]$ substituted mainly on the $O-6$ of the $\beta-\mathrm{D}-\mathrm{Gal} p$ unit by $\beta$-D-Xyl $p$ side stubs, and less with sulfate or methoxy groups, and also on $O-2$ and/or the $O-3$ of the $\alpha$-L-Galp (or 3,6- $\alpha$-L-AnGalp) residues with methoxy and/or sulfate groups [3]; (iv) a sulfated xylogalactan isolated from C. pilulifera composed of alternating 3-linked $\beta$-D-Gal $p$ and 4 -linked $\alpha$-L-Gal $p$ bearing single $\beta$-D-Xyl $p$ substituents in the O-6 position of $\beta$-D-Gal $p$ residues, whereas sulfate and methoxy groups occupy the $O-2$ and $O-3$ positions of $\alpha-\mathrm{L}-\mathrm{Gal} p$ and $O-6$ of $\beta$-D-Gal $p$ units [19]; (v) a xylogalactan extracted from B. cretacea with a similar main chain consisting of $\rightarrow 4)$ - $\alpha$-L-Gal $p$-(1,3)- $\beta$-D-Gal $p$-(1 $\rightarrow$ partially sulfated on the $O-6$ of $\beta$-(1,3)-D-Gal $p$, a feature unique to this species [47]; (vi) a complex xylogalactan produced from L. heterocladum composed of alternating 3-linked $\beta$-D-Gal $p$ and 4-linked $\alpha$-L-Gal $p$ highly substituted principally on the $O-6$ of the $\beta$-D-Gal $p$ residues by $\beta$-D-xylosyl side stubs, and less with methoxy or sulfate groups, and also on the $O-2$ by sulfate or methoxy group of the $\alpha$-L-Gal $p$ or 3,6- $\alpha$-L-AnGal $p$ residues [2]; and finally (vii) a sulfated xylogalactan obtained from Gracilaria caudata composed of alternating residues of 3-linked- $\beta-\mathrm{D}-\mathrm{Gal} p$ and 4-linked-3,6- $\alpha$-L-AnGal $p$ highly substituted by methoxy groups and pyruvic acid acetal. 
The ${ }^{1} \mathrm{H}$ - and ${ }^{13} \mathrm{C}-\mathrm{NMR}$ assignments of JSP and JDP spectra are given in Figures 2 and 3. The spectra showed a high degree of multiplicity, suggesting a great diversity in the $\alpha$-L-Gal $p$ and $\beta-D-G a l p$ backbone, which seems similar to those already published for other corallinans $[2-4,20,47]$. Signals related to the anomeric regions are located in the range $\delta 4.2-5.6 \mathrm{ppm}$ for ${ }^{1} \mathrm{H}-\mathrm{NMR}$ and $\delta$ $100-110$ ppm for ${ }^{13} \mathrm{C}-\mathrm{NMR}[2,3,19]$. The signals at $\delta 103.8 / 4.41$ and correlation of $\delta 4.70 / 3.60$ in the COSY were assigned to the $\rightarrow 3)-\beta-\mathrm{D}-\mathrm{Gal} p-(1,4)-\alpha$-L-Gal $p-(1 \rightarrow$ substituted units (Figure 4$)$, while the signals at $\delta 102.8 / 4,70$ in ${ }^{13} \mathrm{C}$ - and ${ }^{1} \mathrm{H}-\mathrm{NMR}$, respectively, were attributed to the anomeric carbon and proton of $\rightarrow 3)-\beta$-D-Galp-(1,4)-3,6- $\alpha$-L-AnGal $p$ - $(1 \rightarrow$ residues, confirming the main backbone structure of JSP $[3,48]$.
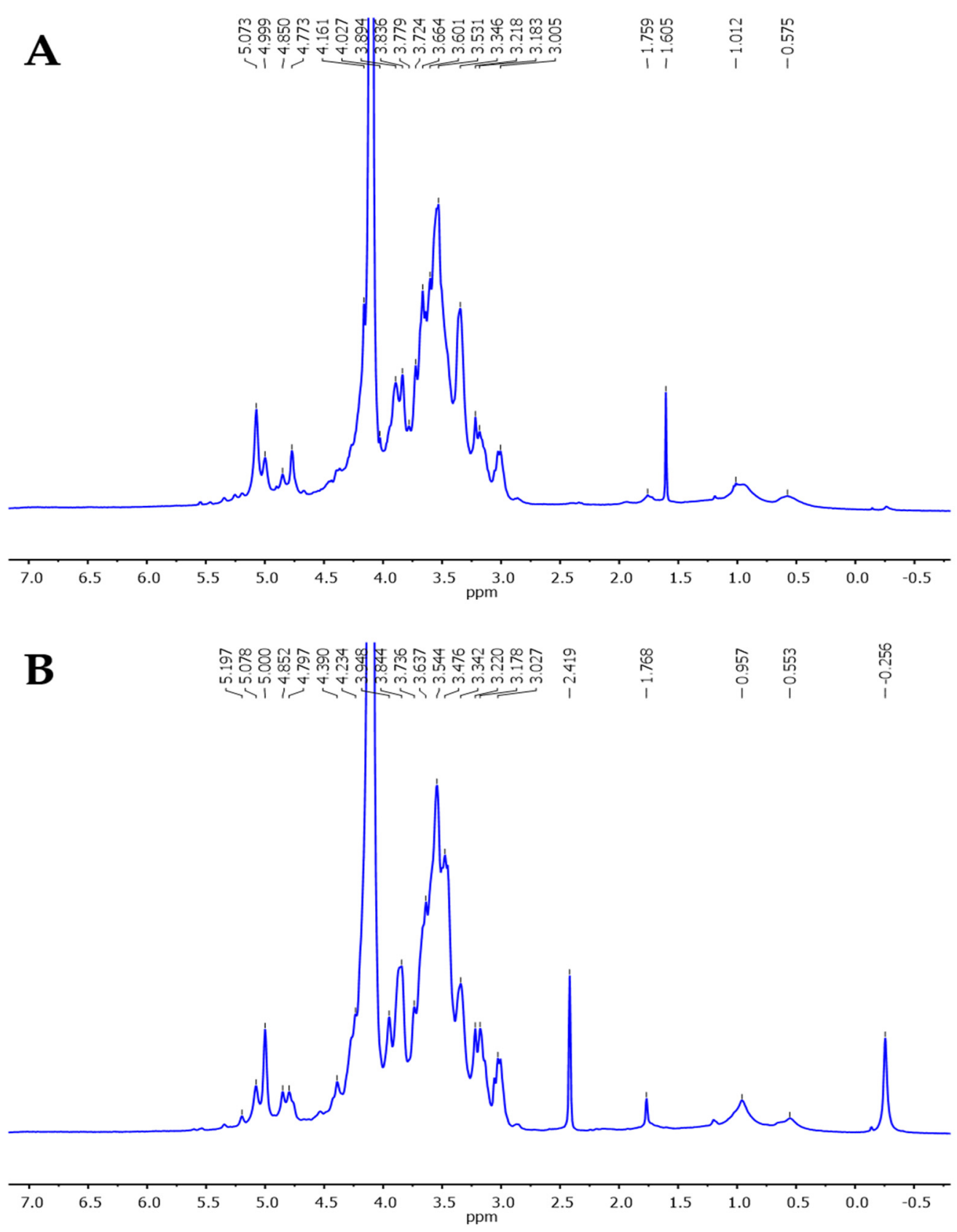

Figure 2. ${ }^{1} \mathrm{H}-\mathrm{NMR}$ spectra of (A) JSP and (B) JDP fractions. The analyses were recorded at $60{ }^{\circ} \mathrm{C}$ for samples in $\mathrm{D}_{2} \mathrm{O}$ solution $(40 \mathrm{~g} / \mathrm{L})$. 

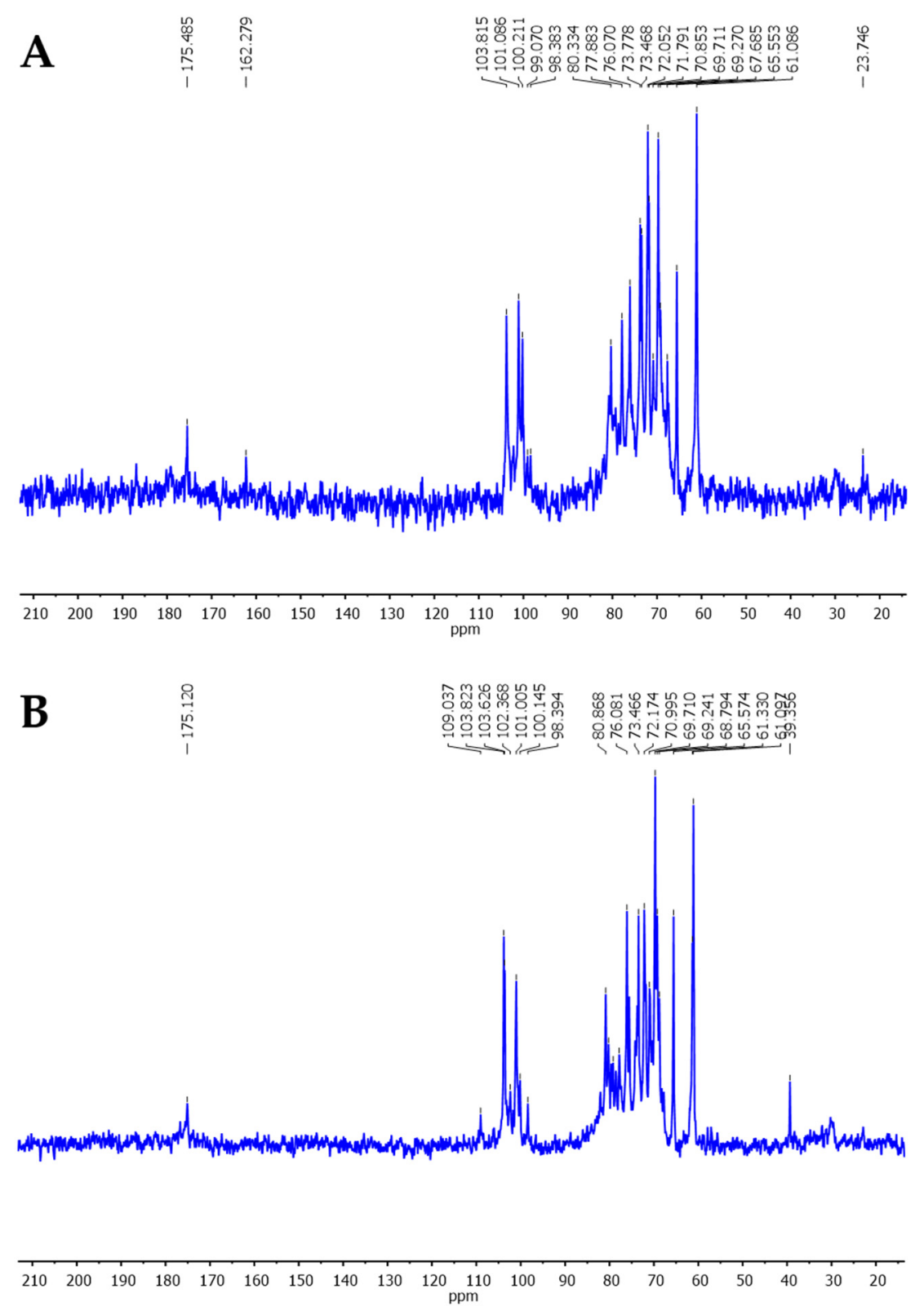

Figure 3. ${ }^{13} \mathrm{C}-\mathrm{NMR}$ spectra at $300 \mathrm{MHz}$ of (A) JSP and (B) JDP fractions. The analyses were recorded at $40 \mathrm{~g} / \mathrm{L}$ in $\mathrm{D}_{2} \mathrm{O}$ solution at $60{ }^{\circ} \mathrm{C}$.

The signals at $\delta 101.09 / 5.07 \mathrm{ppm}$ and correlation of $\delta 5.07 / 3.34(\mathrm{H}-1 / \mathrm{H}-2)$ in the COSY spectrum (Figure 4) were assigned to the anomeric proton of $\alpha-(1,4)-\mathrm{L}-\mathrm{Gal} p$ residues substituted at the $O-3$, mainly by sulfate groups and rarely with methoxy groups [48]. This assignment (at $\delta 101.09 / 5.07 \mathrm{ppm}$ ) was already made to the 3-O-methyl- $\alpha$-L-Gal $p$ unit [3], but, in this case, a sulfate group appeared to be present at this position compared to the JDP spectrum. Two signals at $\delta 5.42 \mathrm{ppm}$ (Figure 2A) and $99.10 \mathrm{ppm}$ (Figure 3A) could be assigned to the $\alpha$-Glc residues in the floridean starch. These assignments were supported by other reports $[2,3]$ and were in accordance with the monosaccharides composition (see Section 3.2.2.). The resonances at $\delta 97.7 / 5.34$ and $98.7 / 5.18 \mathrm{ppm}$ were mainly affected by 3,6-An- $\alpha$-L-Gal $p\left(2-O-\mathrm{SO}_{3}{ }^{-}\right)$and 3,6-An- $\alpha$-L-Gal $p$ (2-O-methyl ether), while the signals at $\delta 98.9 / 5.49$ ppm were assigned to the H-1 of 2-O-methyl- $\alpha$-L-Gal $p$ residues $[3,19]$. The $\alpha$-L-Gal $p$ and 3-Me- $\alpha$-L-Gal $p$ residues were identified at $\delta 5.24 \mathrm{ppm}$ and $\delta 101.5 \mathrm{ppm}$ and the signals at around $\delta$ $100.22 / 5.56 \mathrm{ppm}$ were ascribed to the $\alpha-(1,4)$-linked $\mathrm{L}-\mathrm{Gal} p\left(2-\mathrm{O}-\mathrm{SO}_{3}{ }^{-}\right)$residues [19]. It was possible to assign the ${ }^{13} \mathrm{C}$ - and ${ }^{1} \mathrm{H}$-NMR chemical shifts, corresponding to the $\beta$-D-xylosyl units, as $\delta 104.3 / 4.49$ 
(C-1/H-1), 76.07/3.24 (C-2/H-2), 73.47/3.53 (C-3/H-3), 70.86/3.64 (C-4/H-4), 65.56/3.34 (C-5/H-5) and $\delta 3.89\left({\left.\mathrm{H}-5^{\prime}\right)}^{\prime} \mathrm{ppm}[3,19]\right.$. The ${ }^{1} \mathrm{H} /{ }^{1} \mathrm{H}$ correlations of $\delta 5.07 / 3.38$ could be attributed to the $\mathrm{H}-1 / \mathrm{H}-6$ of $\beta$-(1,3)-6-Me-D-Gal $p$ units linked to $\alpha-(1,4)-\mathrm{L}-$ Gal $p-(1 \rightarrow$ in the NOESY spectrum (Figure 5) $[19,48]$. Overall, all other attributes were consistent with the ${ }^{1} \mathrm{H}^{-}{ }^{1} \mathrm{H}$ COSY and NOESY spectra obtained for the JSP fraction (Figure 5). To conclude, these analyses showed that JSP presents a new and complex polysaccharide structure compared to other xylogalactans of corallinans reported in the literature. Further analyses are needed (enzymatic hydrolysis, etc.) to better apprehend the full structure of JSP.

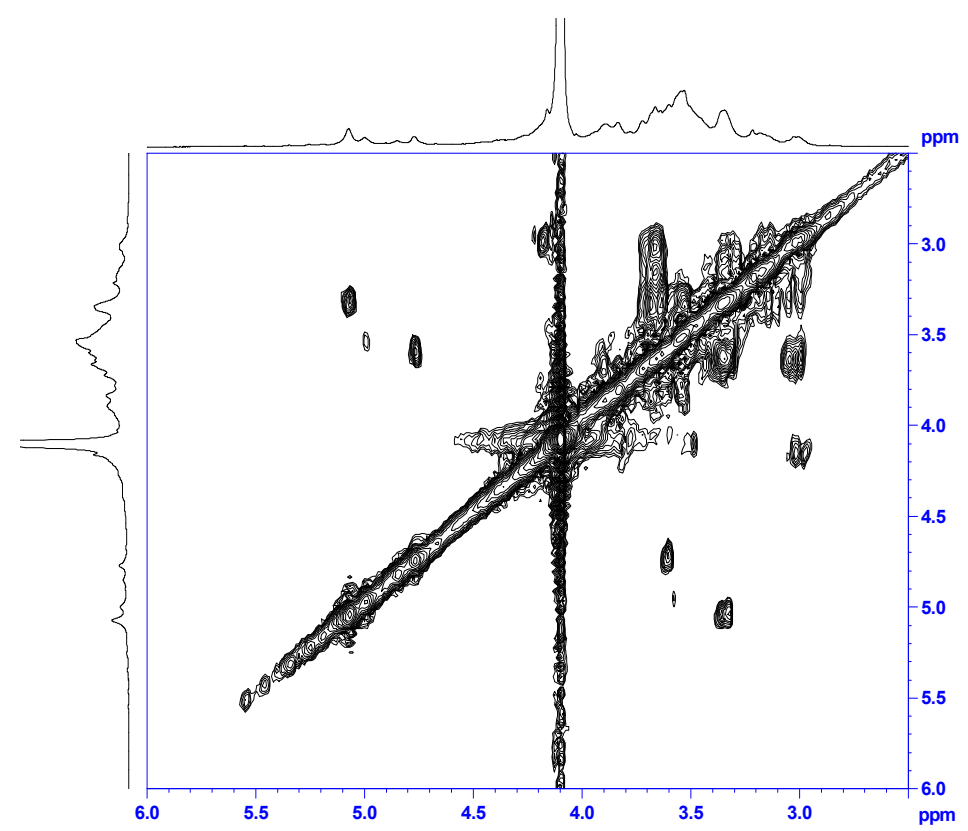

Figure 4. $2 \mathrm{D}^{1} \mathrm{H}-{ }^{1} \mathrm{H}$ COSY NMR correlation spectra of the JSP fraction. The analyses were recorded at $40 \mathrm{~g} / \mathrm{L}$ in $\mathrm{D}_{2} \mathrm{O}$ solution at $60^{\circ} \mathrm{C}$.

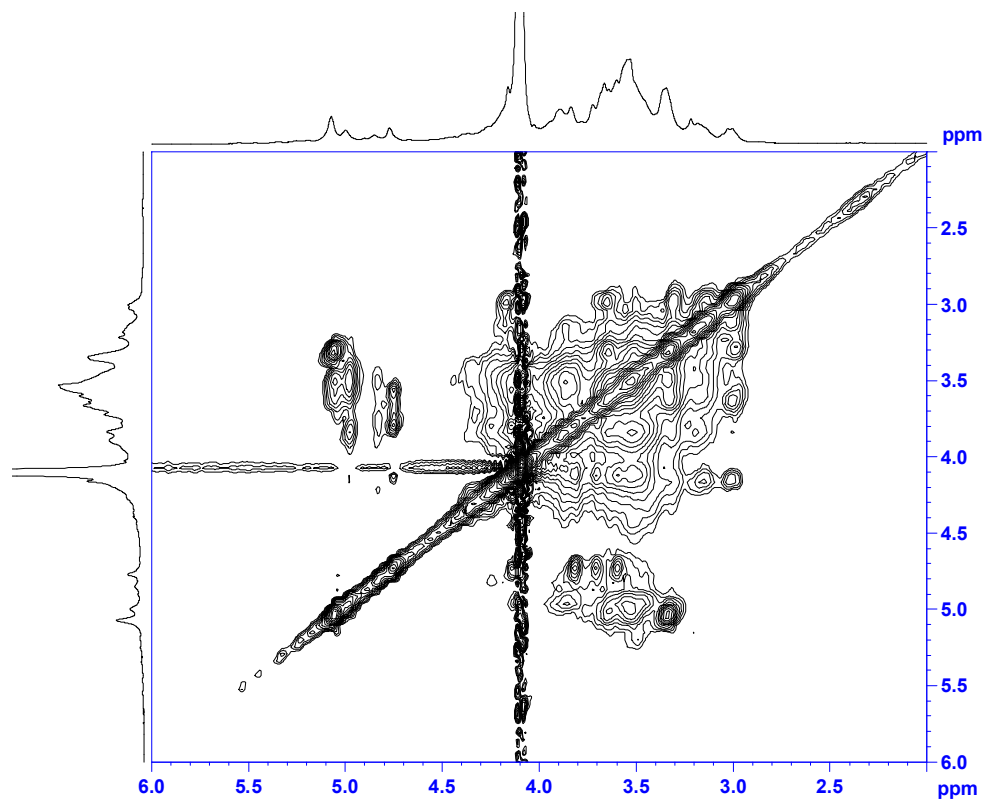

Figure 5. $2 \mathrm{D}^{1} \mathrm{H}^{-1} \mathrm{H}$ NOESY NMR correlation spectra of JSP fraction. The analyses were recorded at $40 \mathrm{~g} / \mathrm{L}$ in $\mathrm{D}_{2} \mathrm{O}$ solution at $60^{\circ} \mathrm{C}$. 


\subsection{Physicochemical Properties of JSP}

\subsubsection{Macromolecular Characteristics of JSP}

As illustrated in Table 3, JSP had a mass-average molecular mass $\left(\mathrm{M}_{\mathrm{W}}\right)$ of $8.0 \times 10^{5} \mathrm{~g} / \mathrm{mol}$ and a number-average molecular mass $\left(\mathrm{M}_{\mathrm{n}}\right)$ of $1 \times 10^{5} \mathrm{~g} / \mathrm{mol}$.

Table 3. Macromolecular characteristics of JSP.

\begin{tabular}{ccccc}
\hline $\mathbf{M}_{\mathbf{w}}{ }^{\mathbf{a}}(\mathrm{g} / \mathbf{m o l})$ & $\mathbf{M}_{\mathbf{n}}{ }^{\mathbf{b}}(\mathrm{g} / \mathbf{m o l})$ & $\mathbf{P D I}^{\mathbf{c}}$ & $\mathbf{R}_{\mathbf{h}}{ }^{\mathbf{d}}(\mathbf{n m})$ & ${ }_{[\eta]}{ }^{\mathbf{e}}(\mathbf{m L} / \mathbf{g})$ \\
\hline $8.0 \times 10^{5}$ & $1 \times 10^{5}$ & 8.0 & 16.8 & 76 \\
\hline
\end{tabular}

${ }^{a} \mathrm{M}_{\mathrm{w}}$ : Weight average molecular weight was measured by SEC-MALLS-DRI, ${ }^{\mathrm{b}} \mathrm{M}_{\mathrm{n}}$ : Number average molecular weight estimated by SEC-MALLS-DRI, ${ }^{c}$ PDI: Polydispersity index $\mathrm{M}_{\mathrm{w}} / \mathrm{M}_{\mathrm{n}}, \mathrm{d}_{\mathrm{h}} \mathrm{R}_{\mathrm{h}}$. Hydrodynamic radius was calculated by SEC-MALLS-DRI, ${ }^{\mathrm{e}}[\eta]$ Intrinsic viscosity was measured by SEC Visco-DRI. Analyses were run in triplicate and the relative standard deviations are less than $5 \%$.

The SEC chromatograms of JSP showed various peaks (DRI and LS), suggesting the presence of various molecular masses and a significant degree of dispersion (data not shown). The PDI value showed JSP heterogeneity and could be due to the presence of floridean starch ( $\alpha$-Glc) contamination and other larger molecular weight xylogalactans $[49,50]$. This last statement is consistent with the literature concerning sulfated galactans from Botryocladia occidentalis [51] and Gracilaria cornea [52] red seaweeds. High $\mathrm{M}_{\mathrm{w}}$ have been described for other sulfated polysaccharides isolated from red seaweeds having values larger than $1 \times 10^{5} \mathrm{~g} / \mathrm{mol}[1,53,54]$. The $\mathrm{M}_{\mathrm{w}}$ value of JSP remained lower than those reported for sulfated xylogalactans extracted from calcareous red algae of the family Corallinaceae, such as C. officinalis, B. orbigniana and J. rubens $[3,14]$. The presence of short chains in the JSP structure could also decrease the $M_{n}$ value and consequently increase the polydispersity $[55,56]$. Note that further purification steps could be done in the future to eliminate the Glc-storage contamination and enhance the structural characterization of this xylogalactan.

Polymer intrinsic viscosity $([\eta] \mathrm{mL} / \mathrm{g})$ indicates the capacity of polymers to enhance the viscosity of fluids, dependent on their physicochemical properties, such as structural conformation, type and degree of branching units, $\mathrm{M}_{\mathrm{w}}$, and solvent property $[33,49]$. The $[\eta]$ of $76 \mathrm{~mL} / \mathrm{g}$ and the hydrodynamic radius $R_{h}$ of $16.8 \mathrm{~nm}$ obtained for JSP suggest a flexible random coil conformation with a value of Mark-Houwink-Sakurada exponent $\alpha$ ranging between 0.5 and 0.8 . [33,49,56]. Finally, the theoretical critical concentration $C^{*}$ of JSP, which can be obtained by ks/[ $\eta$ ] (with $\mathrm{ks}=0,5$ to 1 for coil polysaccharides in water) could range from 6.5 to $13.1 \mathrm{~g} / \mathrm{L}$.

\subsubsection{Rheological Behavior of JSP}

The steady-shear flow curves for the JSP aqueous solutions at different concentrations from $0.25 \%$ to $2.0 \%(w / v)$ at $25{ }^{\circ} \mathrm{C}$ are presented in Figure 6. JSP solutions in water exhibited shear-thinning behavior since the apparent viscosity $\left(\eta, \mathrm{Pa} . \mathrm{s}^{-1}\right)$ decreased with the increasing shear rate $\left(\dot{\gamma}, \mathrm{s}^{-1}\right)$. As illustrated in Figure 6, increasing JSP concentrations from $0.25 \%$ to $2.0 \%(w / v)$ led to an increase in the apparent viscosity of the aqueous solutions, suggesting that polymer chains adopted a more intertwined network. This flow property was in agreement with previous results obtained for other sulfated galactans extracted from G. birdiae and H. durvillei since the authors described a pseudoplastic behavior for two sulfated galactans, considering the same range of concentrations $[12,16]$.

The Ostwald-de Waele model was used to fit the rheological data of the JSP solutions at different concentrations ranging from $0.25 \%$ to $2.0 \%(w / v)$ at $25^{\circ} \mathrm{C}$ over the shear rate from 0.001 to $1000 \mathrm{~s}^{-1}$ (Table 4). Note that the flow behavior index $(n)$ takes the value $n<1$ for fluid exhibiting pseudoplastic or shear-thinning behavior, $n=1$ for Newtonian liquid and $n>1$ for swelling plastic or shear-thickening fluid [57]. As seen in Table 4, the values of the flow behavior index for solutions of JSP in water were lower than 1, confirming the property of a shear-thinning (pseudoplastic) fluid. 


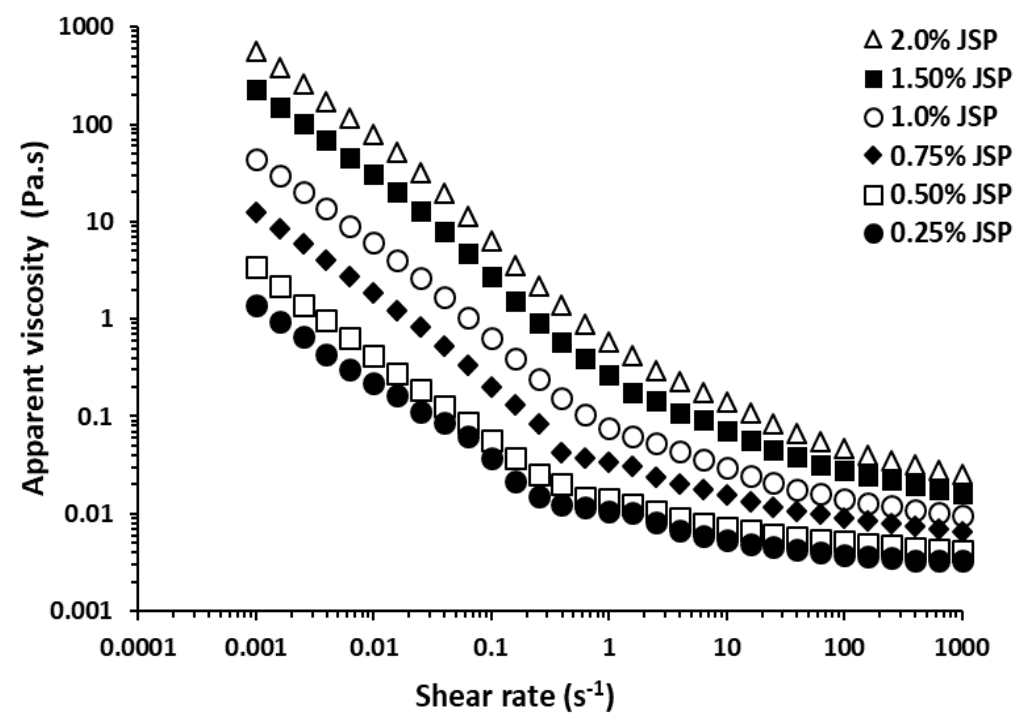

Figure 6. Flow behavior of JSP aqueous solutions at different concentrations ranging from $0.25 \%$ to $2.0 \%(w / v)$ at $25^{\circ} \mathrm{C}$.

Table 4. Consistency and flow behavior index of JSP solutions in water and monovalent salts.

\begin{tabular}{lllccc}
\hline $\mathbf{J S P}(\%, \boldsymbol{w} / \boldsymbol{v})$ & $\mathbf{N a C l}(\mathbf{m o l} / \mathbf{L})$ & $\mathbf{K C l}(\mathbf{m o l} / \mathbf{L})$ & $\boldsymbol{n}$ & $\boldsymbol{k}\left(\mathbf{P a .} \mathbf{s}^{\mathbf{n}}\right)$ & $\boldsymbol{R}^{\mathbf{2}}$ \\
\hline \multirow{3}{*}{$\mathbf{0 . 2 5}$} & 0.0 & 0.0 & $0.54 \pm 0.014$ & $0.030 \pm 0.002$ & 0.99 \\
& 0.5 & 0.0 & $0.58 \pm 0.020$ & $0.028 \pm 0.006$ & 0.98 \\
& 0.0 & 0.5 & $0.60 \pm 0.018$ & $0.022 \pm 0.005$ & 0.98 \\
$\mathbf{0 . 5 0}$ & 0.0 & 0.0 & $0.50 \pm 0.007$ & $0.060 \pm 0.007$ & 0.99 \\
& 0.5 & 0.0 & $0.57 \pm 0.024$ & $0.055 \pm 0.003$ & 0.97 \\
& 0.0 & 0.5 & $0.55 \pm 0.030$ & $0.058 \pm 0.001$ & 0.97 \\
$\mathbf{0 . 7 5}$ & 0.0 & 0.0 & $0.48 \pm 0.004$ & $0.174 \pm 0.001$ & 0.99 \\
& 0.5 & 0.0 & $0.54 \pm 0.020$ & $0.168 \pm 0.016$ & 0.99 \\
& 0.0 & 0.5 & $0.54 \pm 0.024$ & $0.167 \pm 0.014$ & 0.98 \\
$\mathbf{1 . 0}$ & 0.0 & 0.0 & $0.44 \pm 0.011$ & $0.26 \pm 0.012$ & 1.00 \\
& 0.5 & 0.0 & $0.49 \pm 0.008$ & $0.24 \pm 0.018$ & 0.99 \\
& 0.0 & 0.5 & $0.51 \pm 0.005$ & $0.20 \pm 0.022$ & 0.97 \\
$\mathbf{1 . 5 0}$ & 0.0 & 0.0 & $0.43 \pm 0.015$ & $0.60 \pm 0.005$ & 1.00 \\
& 0.5 & 0.0 & $0.47 \pm 0.026$ & $0.55 \pm 0.024$ & 0.97 \\
\multirow{2}{*}{$\mathbf{0} 0$} & 0.0 & 0.5 & $0.45 \pm 0.030$ & $0.57 \pm 0.035$ & 0.99 \\
& 0.0 & 0.0 & $0.40 \pm 0.018$ & $1.30 \pm 0.012$ & 1.00 \\
& 0.5 & 0.0 & $0.42 \pm 0.025$ & $1.25 \pm 0.042$ & 0.98 \\
& 0.0 & 0.5 & $0.43 \pm 0.021$ & $1.22 \pm 0.034$ & 0.98 \\
\hline
\end{tabular}

The effects of temperature and salts $(\mathrm{NaCl}$ and $\mathrm{KCl})$ on the flow properties of JSP solutions $(1.0-2.0 \%, w / v)$ are illustrated in Figure 7. The $\eta$ was found to decrease with the increase in temperatures (Figure 7B) and when adding salts (Figure 7A).

The increase in heat was able to increase the energy dissipation of polysaccharide molecules, which resulted in a breakdown of the weak energy bonds (hydrogen and electrostatic bonds), a decrease in the intermolecular interactions and, consequently, the drop of the flow polymer activation energy $\left(E_{a}\right)[34,57]$. In monovalent salts $\mathrm{NaCl}$ or $\mathrm{KCl}$ solutions $(0.5 \mathrm{~mol} / \mathrm{L})$, intermolecular electrostatic repulsions as well as the number and/or complexity of junction zones between JSP molecules decreased, showing that JSP adopted a more compact conformation because of its weak polyelectrolyte character (low uronic acids content) $[16,33,34]$. As shown in Table 4, the values of $n$ increased in $\mathrm{NaCl}$ and $\mathrm{KCl}$ solutions $\left(0.5 \mathrm{~mol} / \mathrm{L}\right.$ ), by increasing the temperature (from $20^{\circ} \mathrm{C}$ to $60^{\circ} \mathrm{C}$ ) or decreasing the polymer concentration (from $0.25 \%$ to $2.0 \%(w / v)$ ). The consistency index $k\left(\mathrm{~Pa}_{\mathrm{s}} \mathrm{s}^{\mathrm{n}}\right)$ increased with concentration 
independently of the nature of the solution. The $k$ values decreased with adding salts and increasing temperatures [34,57].

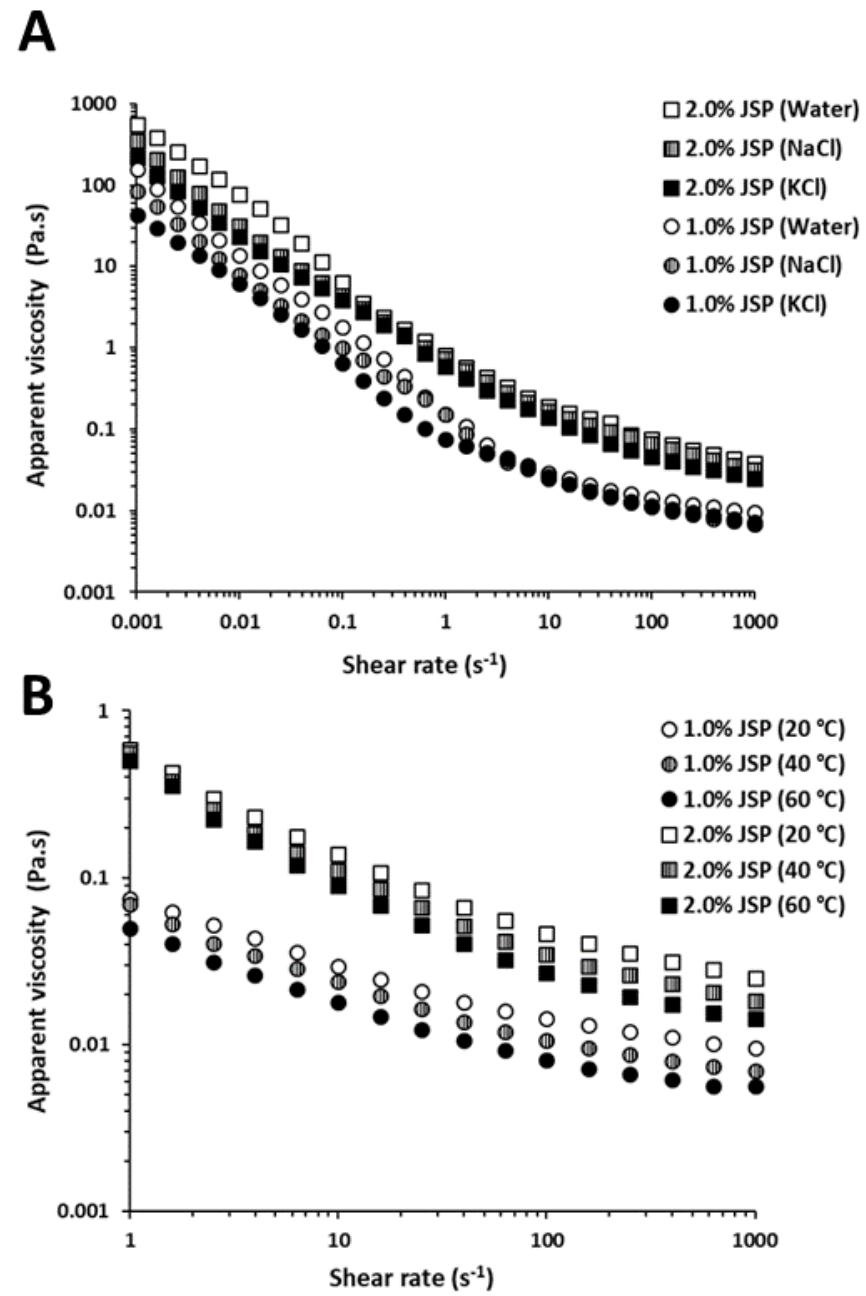

Figure 7. Effect of (A) $\mathrm{NaCl}$ and $\mathrm{KCl}(0.5 \mathrm{M})$ solutions at $25^{\circ} \mathrm{C}$ and (B) temperature on apparent viscosity of JSP solutions $(1.0-2.0 \%, w / v)$.

The frequency dependence of $G^{\prime}$ (storage modulus) and $G^{\prime \prime}$ (loss modulus) of JSP (1.0\% and 2.0\%, $w / v)$ at $25^{\circ} \mathrm{C}$ is described in Figure 8. Typical gel-like behavior was observed since $G^{\prime}$ was higher than $G^{\prime \prime}$, ranging from 0.063 to $62.83 \mathrm{rad} / \mathrm{s}$.

The gap increased between $G^{\prime}$ and $G^{\prime \prime}$ for JSP concentrations $(1.0 \%$ and $2.0 \%, w / v)$ and increasing frequencies $(0.063-62.83 \mathrm{rad} / \mathrm{s})$ showed a significant viscoelasticity of JSP $[33,34,58]$. The dynamic mechanical loss tangent, also named damping factor $\left(\tan \delta=G^{\prime \prime} / G^{\prime}\right)$, is a characteristic parameter for the assessment of viscoelastic behavior [51,52]. The values of $\tan \delta$ were less than 1 and confirmed the elastic behavior of JSP solutions in water. These values slightly dropped with increasing frequencies (from 0.063 to $62.83 \mathrm{rad} / \mathrm{s}$ ) and the polymer energy was dissipated by an elastic flow [34,58].

The critical overlap concentration $\mathrm{C}^{*}(\mathrm{~g} / \mathrm{L}$ or $\%)$ was evaluated by plotting the specific viscosity $\left(\eta_{s p},(\right.$ Pa.s $\left.)\right)$ vs. JSP concentrations from $0.25 \%$ to $2.0 \%(w / v)$ in water (Figure 9$)$. Figure 9 shows that the specific viscosity increased with increasing polysaccharide concentrations (from 1\% to $2.0 \%, w / v$ ) and the change in slope between the two linear segments helped estimate $C^{*}[33,34,59,60]$.

The $\mathrm{C}^{*}$ of JSP at $25^{\circ} \mathrm{C}$ in water was calculated at around $7.5 \mathrm{~g} / \mathrm{L}$ and the slopes of the linear segments below and above the $C^{*}$ were, respectively, 2.5 and 4.5. This practical value of $C^{*}$ was consistent with the theoretical one estimated in Section 3.2.1 (6.5 to 13.1) and the ks value was around 0.57. 


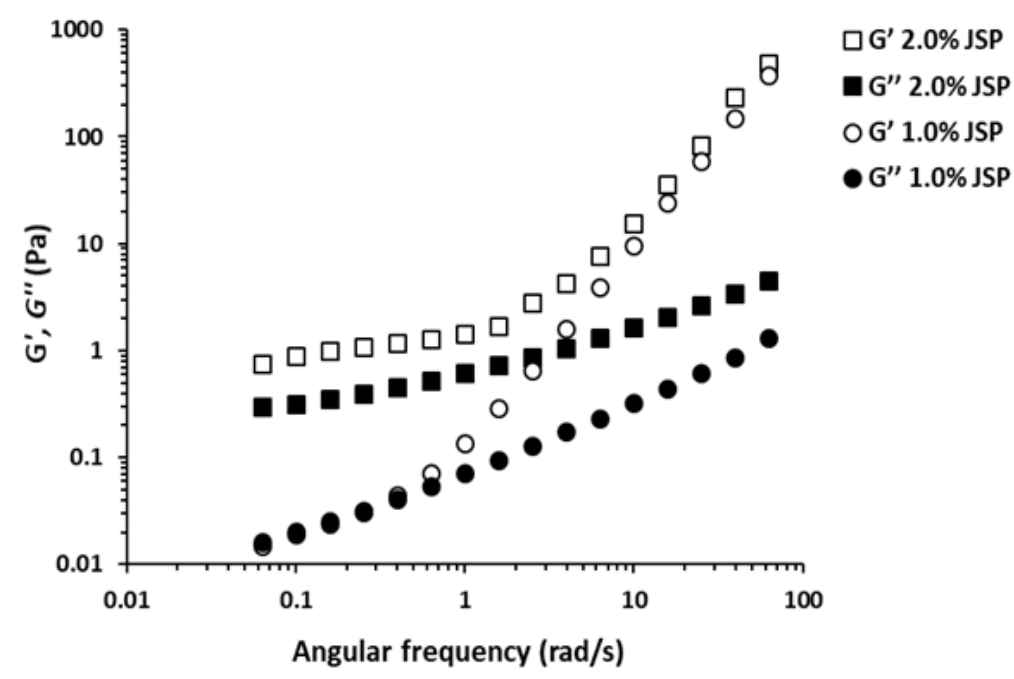

Figure 8. Storage modulus $\left(G^{\prime}\right)$ and loss modulus $\left(G^{\prime \prime}\right)$ vs. angular frequency (rad/s) for JSP aqueous solutions for different concentrations $(1.0-2.0 \%, w / v)$ at $25{ }^{\circ} \mathrm{C}$ in water.

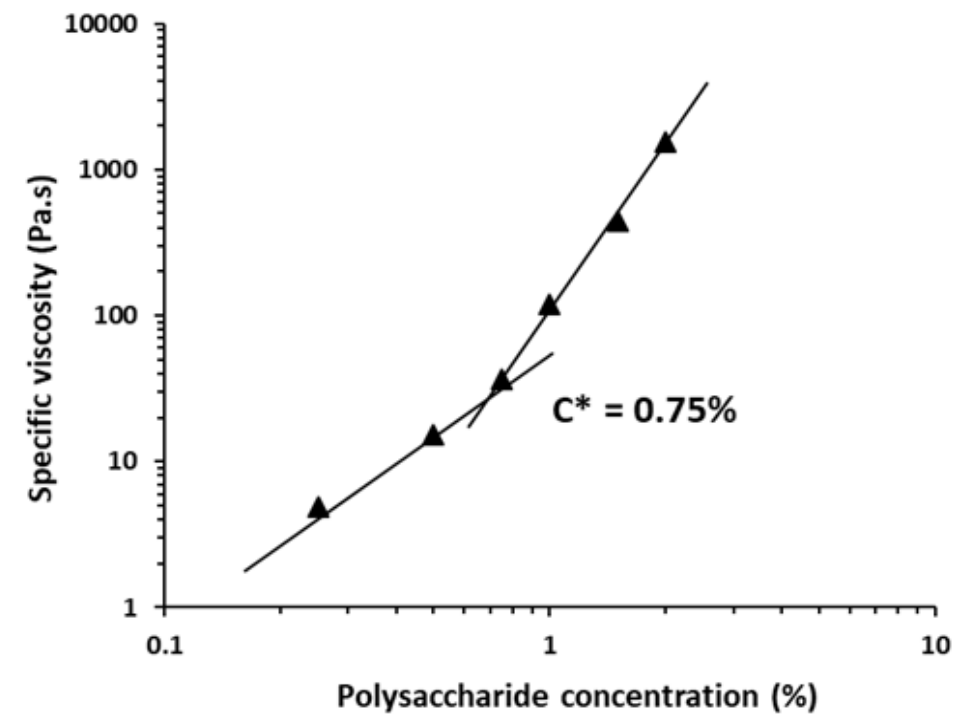

Figure 9. Critical overlap $\left(C^{*}\right)$ concentration obtained from the log-log plot of the specific viscosity $\left(\eta_{s p}\right)$ vs. the concentration of JSP in water at $25^{\circ} \mathrm{C}$.

\section{Conclusions}

The main goals of this paper were to determine the structural features and evaluate the rheological properties of a sulfated xylogalactan-enriched fraction extracted from the Tunisian red seaweed $J$. adhaerens. The structural analyses revealed that JSP $\left(\mathrm{M}_{\mathrm{w}}=8.0 \times 10^{5} \mathrm{Da}\right)$ was mainly composed of an agar-like xylogalactan with a repeating backbone of $(\rightarrow 3)-\beta-\mathrm{D}-\mathrm{Gal} p-(1,4)-\alpha-\mathrm{L}-\mathrm{Gal} p-(1 \rightarrow)_{\mathrm{n}}$ and $(\rightarrow 3)-\beta$-D-Gal $p-(1,4)-3,6-\alpha$-L-AnGal $p-(1 \rightarrow)_{\mathrm{n}}$ substituted mainly on the $O-6$ of the $\beta$-(1,3)-D-Gal $p$ by $\beta$-xylosyl side chains, less with sulfate or methoxy groups, but also on the $O-2$ and $O-3$ of the $\alpha-(1,4)-\mathrm{L}-\mathrm{Gal} p$ with methoxy and/or sulfate groups. The rheological investigations showed that JSP solutions exhibited a shear-thinning behavior and a great viscoelastic character with a critical overlap concentration $\left(\mathrm{C}^{*}\right)$ close to $7.5 \mathrm{~g} / \mathrm{L}$. JSP physicochemical properties are at least as good as other polysaccharides from red marine seaweeds currently used for their functional properties as hydrocolloids. J. adhaerens could be a new feedstock for agaroids in Tunisia even if it seems hard to penetrate the international market of phycocolloids given other main macroalgae producers. Finally, these findings would help the development of novel bioactive polysaccharides for niche markets. 
Author Contributions: F.H. prepared and carried out all the experiments and also wrote the manuscript. C.D., C.G. and G.P. helped perform the extraction, FTIR and GC/MS experiments. J.D., D.L.C. and C.R. carried out the NMR and SEC/MALLS experiments respectively. G.P., P.M. and S.A. conceived and coordinated the work. G.P. revised all the manuscript. All authors have read and agreed to the published version of the manuscript.

Funding: This work has been sponsored by the Tunisian Ministry of higher education and scientific research and Campus France (714305B) (Eiffel scholarship program of excellence, 895151J).

Conflicts of Interest: The authors declare no conflict of interest.

\section{References}

1. Barros, F.C.; Da Silva, D.C.; Sombra, V.G.; Maciel, J.S.; Feitosa, J.P.; Freitas, A.L.; De Paula, R.C. Structural characterization of polysaccharide obtained from red seaweed Gracilaria caudata (J Agardh). Carbohydr. Polym. 2013, 92, 598-603. [CrossRef] [PubMed]

2. Navarro, D.A.; Ricci, A.M.; Rodríguez, M.C.; Stortz, C.A. Xylogalactans from Lithothamnion heterocladum, a crustose member of the Corallinales (Rhodophyta). Carbohydr. Polym. 2011, 84, 944-951. [CrossRef]

3. Navarro, D.A.; Stortz, C.A. The system of xylogalactans from the red seaweed Jania rubens (Corallinales, Rhodophyta). Carbohydr. Res. 2008, 343, 2613-2622. [CrossRef] [PubMed]

4. Takano, R.; Hayashi, J.; Hayashi, K.; Hara, S.; Hirase, S. Structure of a Water-soluble Polysaccharide Sulfate from the Red Seaweed Joculator maximus Manza. Bot. Mar. 1996, 39, 95-102. [CrossRef]

5. Lee, W.-K.; Lim, Y.-Y.; Leow, A.; Thean, C.; Namasivayam, P.; Abdullah, J.O.; Ho, C.-L. Biosynthesis of agar in red seaweeds: A review. Carbohydr. Polym. 2017, 164, 23-30. [CrossRef]

6. Martínez-Sanz, M.; Gómez-Mascaraque, L.G.; Ballester, A.R.; Martinez-Abad, A.; Brodkorb, A.; López-Rubio, A. Production of unpurified agar-based extracts from red seaweed Gelidium sesquipedale by means of simplified extraction protocols. Algal Res. 2019, 38, 101420. [CrossRef]

7. Ghannam, A.; Murad, H.; Jazzara, M.; Odeh, A.; Allaf, A.W. Isolation, Structural characterization, and antiproliferative activity of phycocolloids from the red seaweed Laurencia papillosa on MCF-7 human breast cancer cells. Int. J. Boil. Macromol. 2018, 108, 916-926. [CrossRef]

8. Barahona, T.; Encinas, M.V.; Mansilla, A.; Matsuhiro, B.; Zúñiga, E.A. A sulfated galactan with antioxidant capacity from the green variant of tetrasporic Gigartina skottsbergii (Gigartinales, Rhodophyta). Carbohydr. Res. 2012, 347, 114-120. [CrossRef]

9. Coura, C.O.; De Araújo, I.W.F.; Vanderlei, E.S.O.; Rodrigues, J.A.G.; Quinderé, A.L.G.; Fontes, B.P.; De Queiroz, I.N.L.; De Menezes, D.B.; Bezerra, M.M.; Silva, E.A.A.R.; et al. Antinociceptive and Anti-Inflammatory Activities of Sulphated Polysaccharides from the Red Seaweed Gracilaria cornea. Basic Clin. Pharmacol. Toxicol. 2011, 110, 335-341. [CrossRef]

10. Jie, Y.; Zhang, L.; Chen, P.; Mao, X.; Tang, S. Preparation of agarose sulfate and its antithrombogenicity. J. Wuhan Univ. Technol. Sci. Ed. 2012, 27, 110-114. [CrossRef]

11. Souza, B.W.S.; Cerqueira, M.A.; Bourbon, A.I.; Pinheiro, A.C.; Martins, J.; Coimbra, M.A.; Coimbra, M.A.; Vicente, A.A. Chemical characterization and antioxidant activity of sulfated polysaccharide from the red seaweed Gracilaria birdiae. Food Hydrocoll. 2012, 27, 287-292. [CrossRef]

12. De Araújo, I.W.F.; Vanderlei, E.D.S.O.; Rodrigues, J.A.G.; Coura, C.O.; Quinderé, A.L.G.; Fontes, B.P.; De Queiroz, I.N.L.; Jorge, R.J.B.; Bezerra, M.M.; Silva, E.A.A.R.; et al. Effects of a sulfated polysaccharide isolated from the red seaweed Solieria filiformis on models of nociception and inflammation. Carbohydr. Polym. 2011, 86, 1207-1215. [CrossRef]

13. Silva, R.O.; Dos Santos, G.M.P.; Nicolau, L.; Lucetti, L.; Santana, A.P.M.; Chaves, L.D.S.; Barros, F.C.N.; Freitas, A.L.P.; Souza, M.H.L.P.; Medeiros, J. Sulfated-Polysaccharide Fraction from Red Algae Gracilaria caudata Protects Mice Gut Against Ethanol-Induced Damage. Mar. Drugs 2011, 9, 2188-2200. [CrossRef] [PubMed]

14. Lins, K.O.A.L.; Bezerra, D.P.; Alves, A.P.N.N.; Alencar, N.M.N.; Lima, M.W.; Torres, V.M.; Farias, W.R.L.; Pessoa, C.; De Moraes, M.O.; Lotufo, T.M.D.C. Antitumor properties of a sulfated polysaccharide from the red seaweedChampia feldmannii(Diaz-Pifferer). J. Appl. Toxicol. 2009, 29, 20-26. [CrossRef] [PubMed]

15. Khatri, K.; Rathore, M.S.; Agrawal, S.; Jha, B. Sugar contents and oligosaccharide mass profiling of selected red seaweeds to assess the possible utilization of biomasses for third-generation biofuel production. Biomass Bioenergy 2019, 130, 105392. [CrossRef] 
16. Fenoradosoa, T.; Delattre, C.; Laroche, C.; Wadouachi, A.; Dulong, V.; Picton, L.; Andriamadio, P.; Michaud, P. Highly sulphated galactan from Halymenia durvillei (Halymeniales, Rhodophyta), a red seaweed of Madagascar marine coasts. Int. J. Boil. Macromol. 2009, 45, 140-145. [CrossRef]

17. Bilan, M.I.; Usov, A.I. Polysaccharides of calcareous algae and their effect on calcification process. Биоорганическая Химия 2001, 27, 2-16.

18. Navarro, D.; Navarro, A.D.; Stortz, C.A. Isolation of xylogalactans from the Corallinales: Influence of the extraction method on yields and compositions. Carbohydr. Polym. 2002, 49, 57-62. [CrossRef]

19. Usov, A.I.; Bilan, M.I.; Shashkov, A.S. Structure of a sulfated xylogalactan from the calcareous red alga Corallina pilulifera P. et R. (Rhodophyta, Corallinaceae). Carbohydr. Res. 1997, 303, 93-102. [CrossRef]

20. Cases, M.R.; Stortz, C.A.; Cerezo, A.S. Structure of the 'corallinans'-Sulfated xylogalactans from Corallina officinalis. Int. J. Boil. Macromol. 1994, 16, 93-97. [CrossRef]

21. Dubois, M.; Gilles, K.A.; Hamilton, J.K.; Rebers, P.A.; Smith, F. Colorimetric Method for Determination of Sugars and Related Substances. Anal. Chem. 1956, 28, 350-356. [CrossRef]

22. Monsigny, M.; Petit, C.; Roche, A.C. Colorimetric determination of neutral sugars by a resorcinol sulfuric acid micro-method. Anal. Biochem. 1988, 175, 525-530. [CrossRef]

23. Blumenkrantz, N.; Asboe-Hansen, G. New method for quantitative determination of uronic acids. Anal. Biochem. 1973, 54, 484-489. [CrossRef]

24. Montreuil, J.; Spik, G.; Chosson, A.; Segard, E.; Scheppler, N. Methods of Study of The Structure of Glycoproteins. J. Pharm. Belg. 1963, 18, 529-546.

25. Dodgson, K.; Price, R.; Lash, J.W.; Whitehouse, M.W.; Moretti, A.; Harborne, J. A note on the determination of the ester sulphate content of sulphated polysaccharides. Biochem. J. 1962, 84, 106-110. [CrossRef]

26. Yaphe, W.; Arsenault, G. Improved resorcinol reagent for the determination of fructose, and of 3,6-anhydrogalactose in polysaccharides. Anal. Biochem. 1965, 13, 143-148. [CrossRef]

27. Sloneker, J.H.; Orentas, D.G.; Sloneker, D.G.O.J.H. Pyruvic Acid, a Unique Component of an Exocellular Bacterial Polysaccharide. Nature 1962, 194, 478-479. [CrossRef]

28. Bradford, M.M. A rapid and sensitive method for the quantitation of microgram quantities of protein utilizing the principle of protein-dye binding. Anal. Biochem. 1976, 72, 248-254. [CrossRef]

29. Singleton, V.L.; Orthofer, R.; Lamuela-Raventós, R.M. [14] Analysis of total phenols and other oxidation substrates and antioxidants by means of folin-ciocalteu reagent. Methods Enzymol. 1999, 299, 152-178.

30. Hentati, F.; Delattre, C.; Ursu, A.V.; Desbrières, J.; Le Cerf, D.; Gardarin, C.; Abdelkafi, S.; Michaud, P.; Pierre, G. Structural characterization and antioxidant activity of water-soluble polysaccharides from the Tunisian brown seaweed Cystoseira compressa. Carbohydr. Polym. 2018, 198, 589-600. [CrossRef]

31. Pierre, G.; Graber, M.; Rafiliposon, B.A.; Dupuy, C.; Orvain, F.; De Crignis, M.; Maugard, T. Biochemical Composition and Changes of Extracellular Polysaccharides (ECPS) Produced during Microphytobenthic Biofilm Development (Marennes-Oléron, France). Microb. Ecol. 2011, 63, 157-169. [CrossRef] [PubMed]

32. Pierre, G.; Zhao, J.-M.; Orvain, F.; Dupuy, C.; Klein, G.; Graber, M.; Maugard, T. Seasonal dynamics of extracellular polymeric substances (EPS) in surface sediments of a diatom-dominated intertidal mudflat (Marennes-Oléron, France). J. Sea Res. 2014, 92, 26-35. [CrossRef]

33. Benaoun, F.; Delattre, C.; Boual, Z.; Ursu, A.V.; Vial, C.; Gardarin, C.; Wadouachi, A.; Le Cerf, D.; Varacavoudin, T.; El-Hadj, M.D.O.; et al. Structural characterization and rheological behavior of a heteroxylan extracted from Plantago notata Lagasca (Plantaginaceae) seeds. Carbohydr. Polym. 2017, 175, 96-104. [CrossRef] [PubMed]

34. Hentati, F.; Pierre, G.; Ursu, A.V.; Vial, C.; Delattre, C.; Abdelkafi, S.; Michaud, P. Rheological investigations of water-soluble polysaccharides from the Tunisian brown seaweed Cystoseira compressa. Food Hydrocoll. 2020, 103, 105631. [CrossRef]

35. Zeid, A.A.; Aboutabl, E.; Sleem, A.; El-Rafie, H. Water soluble polysaccharides extracted from Pterocladia capillacea and Dictyopteris membranacea and their biological activities. Carbohydr. Polym. 2014, 113, $62-66$. [CrossRef]

36. Maciel, J.S.; Chaves, L.S.; Souza, B.W.S.; Teixeira, D.I.; Freitas, A.L.; Feitosa, J.P.; De Paula, H.C. Structural characterization of cold extracted fraction of soluble sulfated polysaccharide from red seaweed Gracilaria birdiae. Carbohydr. Polym. 2008, 71, 559-565. [CrossRef] 
37. Chiovitti, A.; Bacic, A.; Craik, D.J.; Kraft, G.T.; Liao, M.-L.; Falshaw, R.; Furneaux, R. A pyruvated carrageenan from Australian specimens of the red alga Sarconema filiforme1Cell-wall polysaccharides from Australian red algae of the family Solieriaceae (Gigartinales, Rhodophyta). For previous instalment, see ref.[1].1. Carbohydr. Res. 1998, 310, 77-83. [CrossRef]

38. Lajili, S.; Ammar, H.H.; Mzoughi, Z.; Amor, H.B.H.; Muller, C.; Majdoub, H.; Bouraoui, A. Characterization of sulfated polysaccharide from Laurencia obtusa and its apoptotic, gastroprotective and antioxidant activities. Int. J. Boil. Macromol. 2019, 126, 326-336. [CrossRef]

39. Chattopadhyay, K.; Mateu, C.G.; Mandal, P.; Pujol, C.A.; Damonte, E.B.; Ray, B. Galactan sulfate of Grateloupia indica: Isolation, structural features and antiviral activity. Phytochemistry 2007, 68, 1428-1435. [CrossRef]

40. Yang, Y.; Liu, D.; Wu, J.; Chen, Y.; Wang, S. In vitro antioxidant activities of sulfated polysaccharide fractions extracted from Corallina officinalis. Int. J. Boil. Macromol. 2011, 49, 1031-1037. [CrossRef]

41. Hentati, F.; Barkallah, M.; Ben Atitallah, A.; Dammak, M.; Louati, I.; Pierre, G.; Fendri, I.; Attia, H.; Michaud, P.; Abdelkafi, S. Quality Characteristics and Functional and Antioxidant Capacities of Algae-Fortified Fish Burgers Prepared from Common Barbel (Barbus barbus). BioMed Res. Int. 2019, 2019, 2907542. [CrossRef] [PubMed]

42. Ben Hlima, H.; Dammak, M.; Karkouch, N.; Hentati, F.; Laroche, C.; Michaud, P.; Fendri, I.; Abdelkafi, S. Optimal cultivation towards enhanced biomass and floridean starch production by Porphyridium marinum. Int. J. Boil. Macromol. 2019, 129, 152-161. [CrossRef] [PubMed]

43. Sudharsan, S.; Giji, S.; Seedevi, P.; Vairamani, S.; Shanmugam, A.; Sadhasivam, S.; Sadhasivam, G.; Palaniappan, S.; Shanmugam, V.; Annaian, S. Isolation, characterization and bioactive potential of sulfated galactans from Spyridia hypnoides (Bory) Papenfuss. Int. J. Boil. Macromol. 2018, 109, 589-597. [CrossRef] [PubMed]

44. Christiaen, D.; Bodard, M. Infrared spectroscopy of agar films from Gracilaria verrucosa (Huds.) Papenfuss. Bot. Mar. 1983, 26, 425-428. [CrossRef]

45. Sekkal, M.; Legrand, P. A spectroscopic investigation of the carrageenans and agar in the $1500-100 \mathrm{~cm}^{-1}$ spectral range. Spectrochim. Acta Part A Mol. Spectrosc. 1993, 49, 209-221. [CrossRef]

46. Villanueva, R.D.; Sousa, A.M.M.; Gonçalves, M.; Nilsson, M.; Hilliou, L. Production and properties of agar from the invasive marine alga, Gracilaria vermiculophylla (Gracilariales, Rhodophyta). Environ. Boil. Fishes 2009, 22, 211-220. [CrossRef]

47. Usov, A.I.; Bilan, M.I. Polysaccharides of algae. 52. The structure of sulfated xylogalactan from the calcareous red alga bossiella cretacea (P. et R.) Johansen (rhodophyta, corallinaceae). Russ. J. Bioorg. Chem. 1998, 24, 123-129.

48. Restrepo-Espinosa, D.C.; Román, Y.; Colorado-Ríos, J.; De Santana-Filho, A.P.; Sassaki, G.L.; Cipriani, T.R.; Martinez, A.M.; Iacomini, M.; Pavao, M.S.G. Structural analysis of a sulfated galactan from the tunic of the ascidian Microcosmus exasperatus and its inhibitory effect of the intrinsic coagulation pathway. Int. J. Boil. Macromol. 2017, 105, 1391-1400. [CrossRef]

49. Khan, B.M.; Qiu, H.-M.; Wang, X.-F.; Liu, Z.-Y.; Zhang, J.-Y.; Guo, Y.-J.; Chen, W.-Z.; Liu, Y.; Cheong, K.-L. Physicochemical characterization of Gracilaria chouae sulfated polysaccharides and their antioxidant potential. Int. J. Boil. Macromol. 2019, 134, 255-261. [CrossRef]

50. Carraher, C.E., Jr. Seymour/Carraher's Polymer Chemistry; CRC: Boca Raton, FL, USA, 2003.

51. Farias, W.R.; Valente, A.P.; Pereira, M.S.; Mourão, P.A. Structure and Anticoagulant Activity of Sulfated Galactans Isolation of a Unique Sulfated Galactan from the Red Algae botryocladia Occidentalis and Comparison of Its Anticoagulant Action with That of Sulfated Galactans from Invertebrates. J. Biol. Chem. 2000, 275, 29299-29307. [CrossRef]

52. Melo, M. Isolation and characterization of soluble sulfated polysaccharide from the red seaweed Gracilaria cornea. Carbohydr. Polym. 2002, 49, 491-498. [CrossRef]

53. Pomin, V.H. Structural and functional insights into sulfated galactans: A systematic review. Glycoconj. J. 2009, 27, 1-12. [CrossRef] [PubMed]

54. Murano, E.; Toffanin, R.; Zanetti, F.; Knutsen, S.H.; Paoletti, S.; Rizzo, R. Chemical and macromolecular characterisation of agar polymers from Gracilaria dura (C. Agardh) J. Agardh (Gracilariaceae, Rhodophyta). Carbohydr. Polym. 1992, 18, 171-178. [CrossRef]

55. Hadj Ammar, H.H.; Hafsa, J.; Le Cerf, D.; Bouraoui, A.; Majdoub, H. Antioxidant and gastroprotective activities of polysaccharides from the Tunisian brown algae. J. Tunis. Chem. Soc. 2016, 18, 80-88. 
56. Ammar, H.H.; Lajili, S.; Ben Said, R.; Le Cerf, D.; Bouraoui, A.; Majdoub, H. Physico-chemical characterization and pharmacological evaluation of sulfated polysaccharides from three species of Mediterranean brown algae of the genus Cystoseira. DARU J. Pharm. Sci. 2015, 23, 1. [CrossRef] [PubMed]

57. Ma, J.; Lin, Y.; Chen, X.; Zhao, B.; Zhang, J. Flow behavior, thixotropy and dynamical viscoelasticity of sodium alginate aqueous solutions. Food Hydrocoll. 2014, 38, 119-128. [CrossRef]

58. Yin, J.-Y.; Wang, J.-Q.; Lin, H.-X.; Xie, M.-Y.; Nie, S.-P. Fractionation, physicochemical properties and structural features of non-arabinoxylan polysaccharide from the seeds of Plantago asiatica L. Food Hydrocoll. 2016, 55, 128-135. [CrossRef]

59. Razmkhah, S.; Razavi, S.M.; Mohammadifar, M.A. Dilute solution, flow behavior, thixotropy and viscoelastic characterization of cress seed (Lepidium sativum) gum fractions. Food Hydrocoll. 2017, 63, 404-413. [CrossRef]

60. Chouana, T.; Pierre, G.; Vial, C.; Gardarin, C.; Wadouachi, A.; Cailleu, D.; Le Cerf, D.; Boual, Z.; El Hadj, M.O.; Michaud, P.; et al. Structural characterization and rheological properties of a galactomannan from Astragalus gombo Bunge seeds harvested in Algerian Sahara. Carbohydr. Polym. 2017, 175, 387-394. [CrossRef]

(C) 2020 by the authors. Licensee MDPI, Basel, Switzerland. This article is an open access article distributed under the terms and conditions of the Creative Commons Attribution (CC BY) license (http://creativecommons.org/licenses/by/4.0/). 